\title{
WestVirginiaUniversity
}

THE RESEARCH REPOSITORY @ WVU

Graduate Theses, Dissertations, and Problem Reports

2010

\section{Veterinary anatomy laboratory impact study}

Bess Catherine Hammill

West Virginia University

Follow this and additional works at: https://researchrepository.wvu.edu/etd

\section{Recommended Citation}

Hammill, Bess Catherine, "Veterinary anatomy laboratory impact study" (2010). Graduate Theses, Dissertations, and Problem Reports. 2961.

https://researchrepository.wvu.edu/etd/2961

This Thesis is protected by copyright and/or related rights. It has been brought to you by the The Research Repository @ WVU with permission from the rights-holder(s). You are free to use this Thesis in any way that is permitted by the copyright and related rights legislation that applies to your use. For other uses you must obtain permission from the rights-holder(s) directly, unless additional rights are indicated by a Creative Commons license in the record and/ or on the work itself. This Thesis has been accepted for inclusion in WVU Graduate Theses, Dissertations, and Problem Reports collection by an authorized administrator of The Research Repository @ WVU. For more information, please contact researchrepository@mail.wvu.edu. 


\title{
Veterinary Anatomy Laboratory Impact Study
}

\section{Bess Catherine Hammill}

Thesis submitted to the Davis College of Agriculture, Natural Resources and Design at West Virginia University in partial fulfillment of the requirements for the degree of

\section{Master of Science} in Agriculture and Extension Education

Deborah A. Boone, Ph.D., Chair

Harry N. Boone, Jr., Ph.D.

Margaret A. Minch, DVM

Division of Resource Management

\author{
Morgantown, West Virginia \\ 2010
}

Keywords: Laboratory, Associative Learning, Academic Aptitude, Specimens 


\section{ABSTRACT \\ Veterinary Anatomy Laboratory Impact Study \\ Bess Catherine Hammill}

This study examines the scholastic impact and opinion of learning in the anatomy laboratory as it relates to the lecture. The teaching of Animal Anatomy in the Animal Science department has traditionally been taught via classroom lecture and supported with a textbook. This study compares one scholastic semester without a laboratory and another scholastic semester offering a laboratory in partnership with the traditional lecture. The students without a laboratory were examined by means of their final grades in comparison with the laboratory and lecture combination. In order to acquire perspectives on the impact the laboratory had on student learning a survey was offered to participating laboratory students at the end of the semester. Standardized test scores ACT and SAT were found to be better predictors of students final grades then was participation in the optional laboratory experience. 


\section{DEDICATION}

I would like to dedicate my study to all of those people in my life who have reminded me daily that I can do anything I set my mind to, especially my family and friends.

Thanks Dad for always seeing the positive no matter what and teaching me to enjoy whatever life brings.

Thanks to Jen Lydon for encouraging all my crazy dreams and aspirations, and having a little fun along the way.

Thanks Shiloh for always being there in the worst and best moments to comfort and push me when I needed it the most.

I couldn't have done this without my biggest cheerleader, my mother.

I would also like to dedicate this study to the students who will become the future of veterinary medicine and animal industries. 


\section{ACKNOWLEDGEMENTS}

I would like to take this time to thank the Davis Michael Committee for the funds to make this laboratory a reality for the anatomy students and myself.

I would like to thank my committee, Dr. Deborah Boone, Dr. Harry Boone, and Dr. Margaret Minch for all the time and patients they have shown during my Master's program and creating the animal anatomy laboratory.

Thank you to all the people who took the time to help me during the study: Dr. Dennis Smith, Dr. Paul Lewis, Gretchen Riggs, Lindsey Triplet, and Gloria Nestor.

Thank you -to Ms. Alice Compton for her time it took to make all the copies for my study. 


\section{TABLE OF CONTENTS}

ABSTRACT

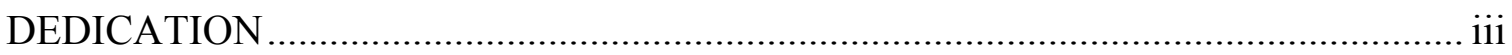

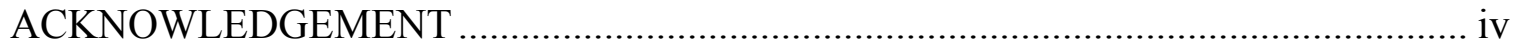

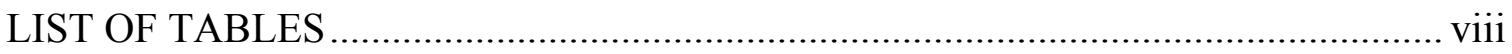

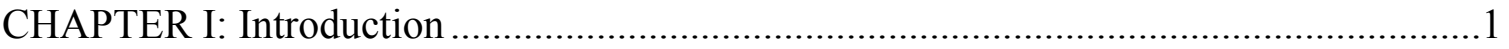

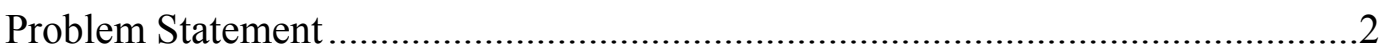

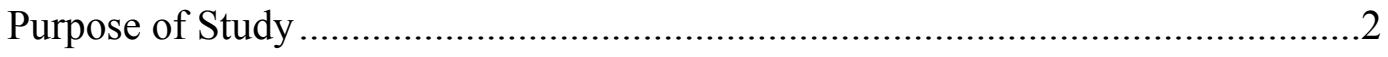

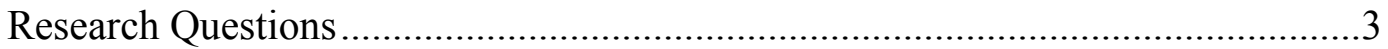

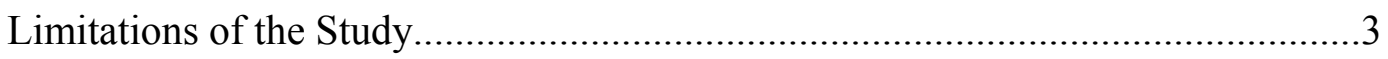

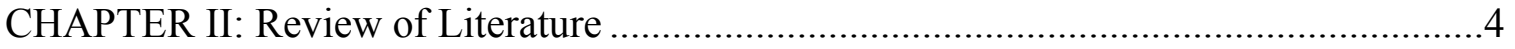

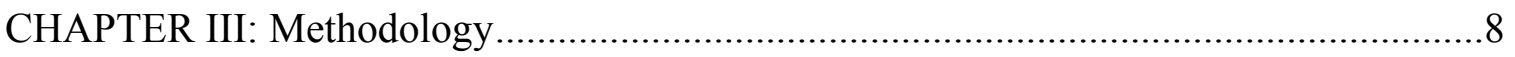

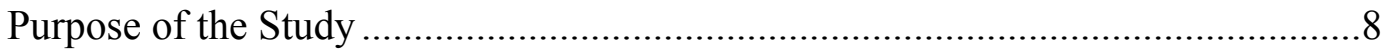

Research Questions ...............................................................................

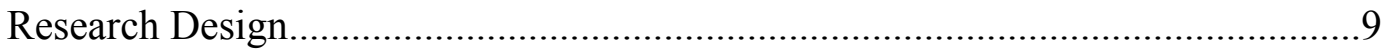

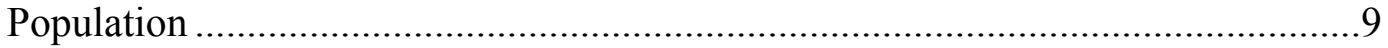

Instrumentation ................................................................................. 10

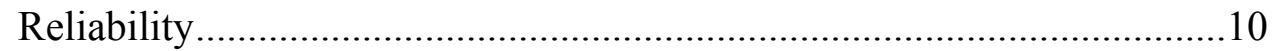

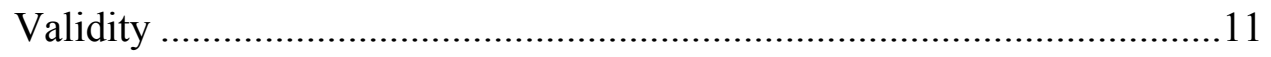

Data Collection Procedures........................................................................ 11

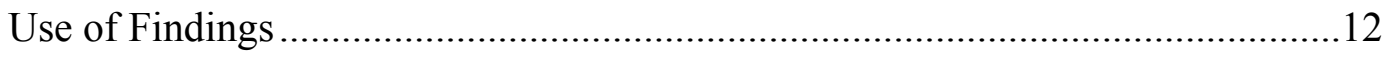

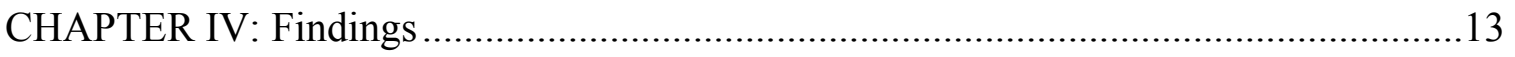

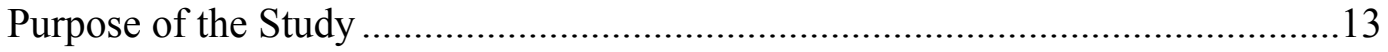


Research Questions ……………….........................................................13

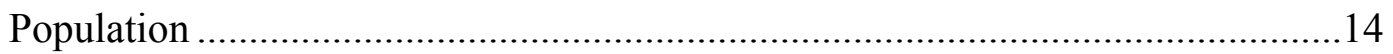

Analysis of Covariance Comparing Final Grades ................................................16

Students' Perceptions of the Value of the Laboratory Activities ...........................17

Responses to Open-ended Questions about Laboratory Experiences....................29

CHAPTER V: Summary, Conclusions, and Recommendations ........................................30

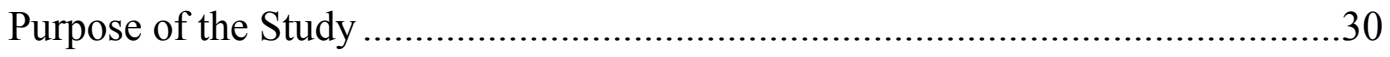

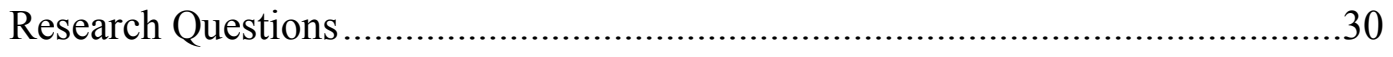

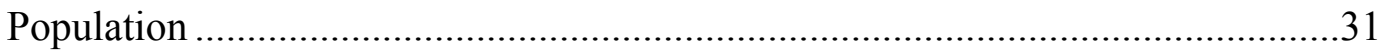

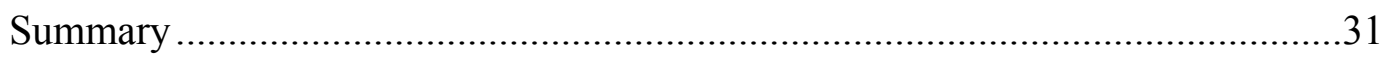

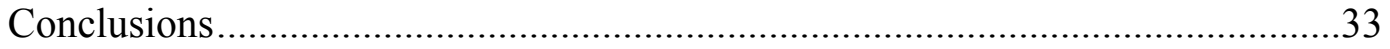

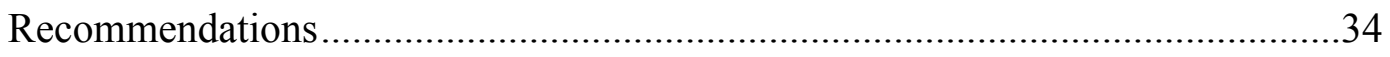

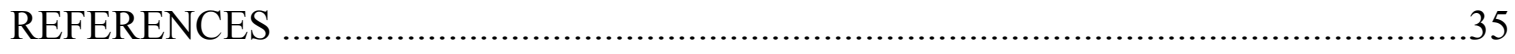

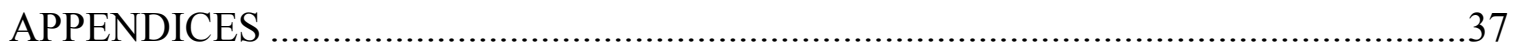

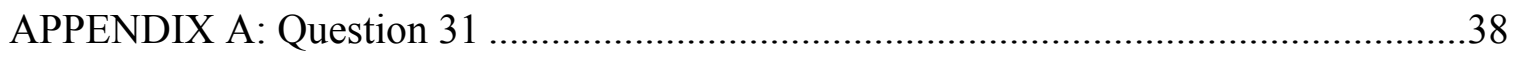

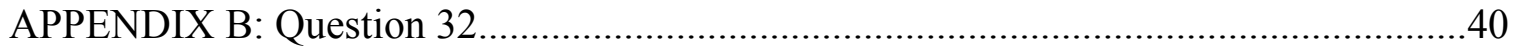

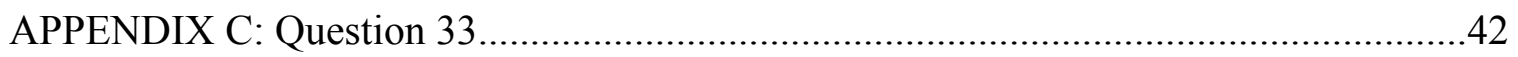

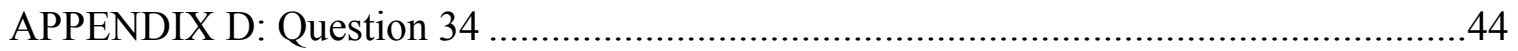

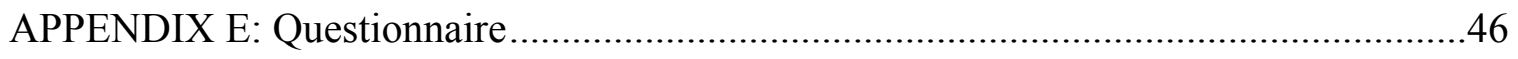

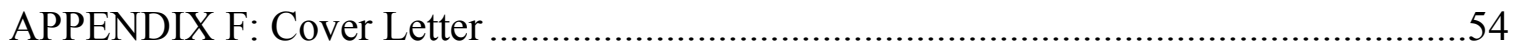

VITA 


\section{LIST OF TABLES}

Table Title Page

$1 \quad$ Laboratory Availability and Participation .................................................. 14

$2 \quad$ Population Distribution by ACT Scores ...................................................... 15

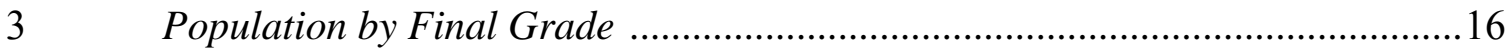

$4 \quad$ Analysis of Covariance Comparing Final Grades in Veterinary Anatomy

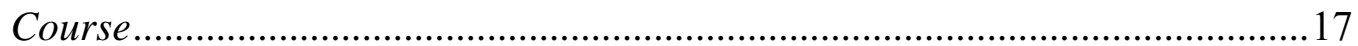

$5 \quad$ Responses to Objective Sections of the Anatomy Survey ...................................19

6 Class Standing of Students Enrolled in 2009 Animal Anatomy

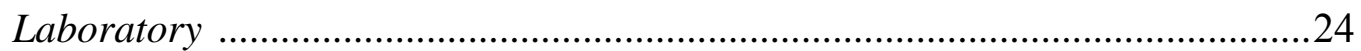

7 Past Experience with Animal Dissection of Students in 2009 Animal

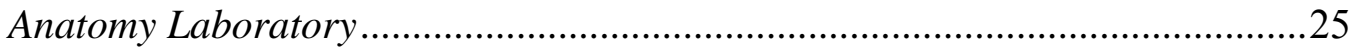

$8 \quad$ Students Applications to Veterinary School.................................................25

$9 \quad$ Plans following Undergraduate in Order of Preference .................................26

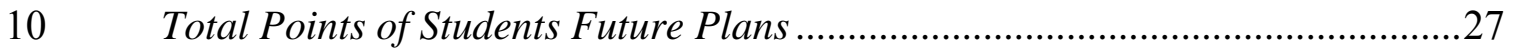

11 Veterinary Schools Where Students Have or Plan on Applying ........................28 


\section{CHAPTER I}

\section{Introduction}

Many students enroll in colleges of agriculture each year with the dream of becoming a veterinarian. Countless students from the university search for ways to relate what is gleaned from the classroom and then apply it to daily life. Educational psychologist Jean Paiget's theory of cognitive development suggests that learning is optimal when the person has interaction with the material they are learning (Paiget, 1954). Webster's dictionary defines anatomy as, "the art of separating the parts of an organism in order to ascertain their position, relations, structure, and function" (MerriamWebster's Online Dictionary). Students who take the animal anatomy lab get the opportunity to explore feline, canine, ovine, bovine, and swine anatomy directly from specimens. Organs, bones, and systems once depicted through two-dimensional diagrams and words now become actual learning tools that can be touched, maneuvered, and discovered. The purpose of the class is to explore what students have learned in formal lecture in an interactive laboratory (M. Minch, personal interview, March 20, 2009).

The pre-vet curriculum is loaded with courses that require a strong science background. Anatomy is one course that is considered to be an advanced science elective. Anatomy has been a vital part of understanding the science of how the body works. The study of “... animal models bridge basic science with human medicine...” (NCRR Strategic Plan 2009-2013: Translating Research from Basic Discovery to Improved Patient Care, 2007). West Virginia University opened as a College of Agriculture in 1867. The West Virginia University Davis College lists on their website what the college experience will provide for the students, "Today students gain practical knowledge and 
skills outside the classroom..." (Davis College of Agriculture, Natural Resources, and Design, 2009).

Many pre-veterinary students will learn better if the education includes experiential learning. Nearly the entire required science courses for veterinary require a laboratory with that course. In 2009 Division of Animal Nutritional Sciences opened an animal anatomy laboratory. The laboratory provides students the opportunity to experience animal anatomy first hand.

\section{Problem Statement}

Thousands of students attend anatomy lectures all over the country. Many human anatomy courses require a cadaver laboratory, so the question arises, what is the potential impact of an animal anatomy lab? Researchers have described the value of problembased learning in the application of clinical knowledge, specifically recognizing increased knowledge retention. Problem-based learning is a teaching method used to engage students and requires them to apply knowledge, compared with rote memorization (Beers \& Bowden, 2005). What is the impact of the addition of a 'hands on' laboratory in conjunction with a traditional lecture in animal anatomy on student learning?

\section{Purpose of the Study}

The purpose of the study was to evaluate the effect of a hands-on laboratory experience on student comprehension of animal anatomy concepts. The study also sought to explore student's perceptions of the effectiveness of the laboratory. The results will provide insight to the instructors and administrators on how students learn the material best. The information may be used to improve existing laboratories or establish laboratories in other classes that are currently lecture only. 


\section{Research Questions}

The objectives of the study are reflected in the following research questions:

1. What is the effect of the laboratory experience on grades for determining the learner's academic success in the animal anatomy course?

2. Do any significant differences exist between the grades of students who participated in the laboratory and those who did not take the optional laboratory?

3. What were the student's perceptions and feelings about the laboratory being offered in conjunction with the lecture?

4. Are the student's ACT/SAT scores a better predictor of their course grades regardless of the addition of the hands-on laboratory?

5. Should the laboratory be continued as an elective or required?

\section{Limitations of the Study}

One limitation of this study was the accessible population. The anatomy course is only offered during spring semesters. The classes were limited to fewer than thirty students per semester. The first semester a laboratory was not offered. The second semester an optional laboratory was offered, however, only seventeen students elected to enroll in the optional laboratory. This limited the number of students which could be included in the study. 


\section{CHAPTER II}

\section{Review of Literature}

Often testing and other specific assignments are used to assess student academic success; however the type of learning environment can play a role in a student's academic success as well. Bolman (1968) notes, “A person’s beliefs about himself and his ways of perceiving and relating to other people are deeply rooted in his learning history and tend to be difficult to change (p. 1)." Student's perceptions of which type of learning is most effective varies based on individual learning styles. Interactive learning reemerges in many classrooms, to accommodate multiple learning styles, studies conducted at a young age have shown that for science based courses, students tend to do better with lecture material when it's combined with a laboratory (Odubunmi, 1991).

Professors want their students not only to hear and learn the material, but to apply it in daily life. This method of teaching where the learner is engaged in the material can be a key to understanding subject material. As Universities push their students for academic excellence, many of the science fields like biology and human medicine begin teaching technical skills early to undergraduate. Replicating the lecture material gives the students an opportunity to test their knowledge in a safe laboratory environment. This discovery-based and problem-based approach encourages learners to explore their subject more in depth than just a traditional lecture atmosphere (Johnston \& McAllister, 2008).

In 2008, Johnston and McAllister, tested student's perceptions of how a laboratory component played a role in the understanding of lecture material. The researchers looked at the student's perceptions and opinions, while acknowledging the challenge of using the teaching simulations that lacked the same impact of real-life 
clinical situation. The study found that knowledge retention was significant due to the fact that students were engaged in problem-based active learning instead of passively learning (Johnston \& McAllister, 2008). Through the teaching simulations, they were able to expose the learners to a wide array of real anatomical parts, which closely resembles what they would observe in a real life situation.

An overwhelming number of students found the anatomy laboratory to be a positive factor and supported continuation. An overwhelming majority (97\%) of the learners thought the laboratory aided them in gaining information. Another $94 \%$ felt that the laboratory added to the information presented in the lecture material. The most significant finding from the study was that $97 \%$ of the participants thought that the laboratory helped them better understand the information presented in lecture (Johnston \& McAllister, 2008).

Students can feel that a laboratory is beneficial, but the question arises whether we can statically prove that it helps their academic performance. In 2005, Beers \& Bowden tested the concept of knowledge retention resulting from a laboratory paired with a lecture versus a lecture without a laboratory. The study presented problem-based learning (PBL) as the foundation of the laboratory. The PBL had a strong focus on the process through which that knowledge is applied. Problem-based learning focuses on the processes that support more critical thinking, creativity, team work, research skills, motivation for learning, self-esteem, and professionalism (Beers \& Bowden, 2005).

No significant difference was found when comparing the final scores from laboratory versus non-laboratory lectures. The researcher tested the students again one year later, and found knowledge retention was higher for those who participated in the 
laboratory in contrast to those without the laboratory. While this study has shown some effects on knowledge retention, the results have been hard to reproduce. No studies have been conducted or tested to determine the long-term retention effects of PBL laboratory settings combined with a traditional lecture. This study showed promising results and encourages the investigation of information retention over periods of time. While the laboratory did not show significant immediate effect, over time the knowledge retention was elevated. Students expressed their appreciation of the laboratory and indicated they had a positive experience (Beers \& Bowden, 2005).

Researchers have examined whether or not student's academic success or achievement is predetermined. Many colleges look at standardized testing as one of the factors that determines scholastic achievement. The college admittance process often begins with standardized testing such as the Scholastic Aptitude Test (SAT) or American College Testing (ACT). Universities determine student acceptance by using these scores, along with student GPA. The SAT-ACT concordance tables can be used to determine equivalent of ACT and SAT score (SAT-ACT Concordance Tables, 2010). The ACT is shown to have significant correlations between with and several standard IQ tests, which can correspond with academic success later on in a college setting (Koenig, Frey, \& Detterman, 2008). The ACT score can be an indicator of academic aptitude and is often used by institutions of higher education as an admission standard.

In conclusion, these studies cover three main areas of concern for animal anatomy laboratory. The ACT/SAT was shown to be a good gauge of academic aptitude. The ACT score is shown to have significant correlations with I.Q. testing. The better students scored on their ACT the better they did in higher levels of education. Despite the fact that 
an ACT can play a factor in academic success, it doesn't determine the student's feelings on the effectiveness of a laboratory. Many students felt positive about the laboratory and believed it helped them better comprehend the subject material and also gave real experience to what they had covered in a lecture setting, and overtime its possible for the laboratory to produce better knowledge retention. 


\section{CHAPTER III}

\section{Methodology}

\section{Purpose of the Study}

The purpose of the study was to evaluate the effect on student comprehension of animal anatomy concepts with the addition of a hands-on laboratory experience. The study also sought to explore student's perceptions of the effectiveness of the laboratory. The results will provide insight to the instructors and administrators on how students learn the material best. The information may be used to improve existing laboratories or establish laboratories in other classes that are currently lecture only.

\section{Research Questions}

The objectives of the study are reflected in the following research questions:

1. What is the effect of the laboratory experience on grades for determining the learner's academic success in the animal anatomy course?

2. Do any significant differences exist between the grades of students who participated in the laboratory and those who did not take the optional laboratory?

3. What were the student's perceptions and feelings about the laboratory being offered in conjunction with the lecture?

4. Are the student's ACT/SAT scores a better predictor of their course grades regardless of the addition of the hands-on laboratory?

5. Should the laboratory be continued as an elective or required? 


\section{Research Design}

A quasi-experimental design using a nonrandomized control group with a posttest design was used for this study. According to Ary, Jacobs, Razavieh \& Sorensen (2006) nonrandomized control group design is the most prevalent quasi-experimental design used in educational research when the classes cannot be randomized to accommodate a research study. Students self selected the semester they took the animal anatomy course in the Department of Animal and Nutritional Sciences at West Virginia University. The control group consisted of students enrolled in the animal anatomy class during spring semester 2007, where no laboratory was offered. Students enrolled spring semester 2009 comprised the experimental group, where they self selected whether or not they enrolled in the optional animal anatomy laboratory to accompanying the lecture. The lecture instructor was the same for both semesters. Act scores were used as a covariant to equalize the students on academic ability.

\section{Population}

The population consisted of students enrolled in the animal anatomy course in the Department of Animal and Nutritional Sciences at West Virginia University during Spring semesters of 2007 and 2009 (N=47). The 2007 animal anatomy course was taught as lecture only with no laboratory offered $(\mathrm{N}=23)$. In 2009 an elective laboratory was offered to all students in addition to the lecture. Students self selected whether or not they took the laboratory in conjunction with lecture. Sixteen of the twenty-four $(66 \%)$ students enrolled in the animal anatomy course in 2009 elected to take the lecture laboratory combination, while eight students $(33 \%)$ took only the lecture portion of the course. 


\section{Instrumentation}

The instrument used to evaluate the student's perceptions of the laboratory was an in lab questionnaire. The questionnaire covered a wide range of material including student's past experiences in dissection, student's perceptions of the lab's benefits, and their plans for the future. The researcher developed an instrument modeled after a survey conducted on a nursing laboratory (Johnston \& McAllister, 2008).

The first 23 questions dealt with their perceptions of the laboratory and the effects the lab had on the lecture experience. The remaining 35 questions covered demographics including year in school, work experience, and future plans.

The second portion of research was conducted using the grades and academic success using the student's ACT scores. The grades along with their ACT scores were processed through the Statistical Package for the Social Sciences system (S.P.S.S.).

Academic achievement in the course was measured using final course grades earned in the anatomy lecture. ACT and/or SAT scores were collected to be used as a covariant in the study. The covariant was required to equalize the students on academic abilities (Koenig, Frey, \& Detterman, 2008).

Reliability. Reliability was established on the survey instrument by using Spearman-Brown split half statistic. The reliability of the instrument was determined to be exemplary with a Spearman-Brown coefficient of 0.69 (Robinson, Wrightsman, \& Shaver, 1991).

Reliability was established on the instrument grade vs. final grades by using Spearman-Brown split half statistic. The reliability of the instrument was determined to 
be exemplary with a Spearman-Brown coefficient of 0.96 (Robinson, Wrightsman, \& Shaver, 1991).

Validity. In order for an instrument to be relevant to the study the instrument should be valid. The study was presented to a panel of experts to establish content and face validity. The panel of experts consisted of a Veterinarian/Anatomy Professor in Animal and Nutritional sciences and faculty in Agricultural and Extension Education. All the individuals had extensive experiences in extension classroom settings and veterinary anatomy. The panel of experts determined that both instruments had face and content validity.

\section{Data Collection Procedures}

The student's final grades were calculated from four main exams, eight quizzes, and a final exam. These grades were then matched by a university official to the student's SAT or ACT scores. All identifying information was then destroyed and replaced with an identification number to protect the student's privacy. The researcher then converted the SAT scores into ACT scores using SAT-ACT Concordance Tables (2010). Random student identification code, which protected their identity, was entered into an Excel spreadsheet along with their ACT scores or equivalents and the student's final grade for the course. The Excel spreadsheet information was uploaded into SPSS for data analysis. Descriptive analyses were run on the data.

A faculty member distributed the survey with no vested interest in the study during lecture on the final day of classes, along with a cover letter explaining the study and how their participation in the survey was totally voluntary. The survey was collected upon completion and returned to a non-related faculty member. The professor was not 
present during the time students completed the questionnaire. There was a $100 \%$ response rate from students who participated in the laboratory; therefore, there was no need to calculate non response error. The survey data were entered into a spread sheet in Excel and analyzed using SPSS to get general opinions from the learners.

The study used official class lists to avoid frame error. A census was conducted, so there was no sampling error. Selection error was controlled by eliminating duplicates. The instrument was found to be reliable and valid by a panel of professors which have expensive back grounds in questionnaires and veterinary anatomy.

\section{Use of Findings}

The findings from this study will be used to help understand the learner's perceptions of the laboratory effects on lecture comprehension and to also calculate the academic effects of the laboratory on the students final lecture grade. This information gathered will be presented to the animal science department in the hope of gauging the benefits of the laboratory and lecture combinations. The findings should also indicate if the ACT can be a good estimate on how successful the students can be academically. 


\section{CHAPTER IV}

\section{Findings}

\section{Purpose of the Study}

The purpose of the study was to evaluate the affect on student comprehension of animal anatomy concepts with the addition of a hands-on laboratory experience. The study also sought to explore student's perceptions of the effectiveness of the laboratory. The results will provide insight to the instructors and administrators on how students learn the material best. The information may be used to improve existing laboratories or establish laboratories in other classes that are currently lecture only.

\section{Research Questions}

The objectives of the study are reflected in the following research questions:

1. What is the effect of the laboratory experience on grades for determining the learner's academic success in the animal anatomy course?

2. Do any significant differences exist between the grades of students who participated in the laboratory and those who did not take the optional laboratory?

3. What were the student's perceptions and feelings about the laboratory being offered in conjunction with the lecture?

4. Are the student's ACT/SAT scores a better predictor of their course grades regardless of the addition of the hands-on laboratory?

5. Should the laboratory be continued as an elective or required? 


\section{Population}

The population consisted of students enrolled in the animal anatomy course in the Department of Animal and Nutritional Sciences at West Virginia University during Spring semesters of 2007 and $2009(n=47)$. The 2007 animal anatomy course was taught as lecture only with no laboratory offered (n=23). In 2009 an elective laboratory was offered to all students in addition to the lecture. Students self selected whether or not they took a laboratory in conjunction with the lecture. Sixteen of the twenty-four (66\%) students enrolled in the animal anatomy course in 2009 elected to take the lecture laboratory combination, while eight students (33\%) took only the lecture portion of the course. Of the 23 students in the 2007 class, $100 \%(\mathrm{~N}=23)$ did not have a laboratory available. In the 2009 class 24 students were enrolled in the lecture, of which the 24 students $(n=8,33.3 \%)$ of the students chose not to participate in the laboratory. Sixteen of the students in 2009 chose to participate in the optional laboratory $(n=16,66.7 \%)$ (see Table 1).

Table 1

Laboratory Availability and Participation

\begin{tabular}{lcccc}
\hline & \multicolumn{3}{c}{2007} & \multicolumn{2}{c}{2009} \\
\cline { 2 - 5 } & $\mathrm{N}$ & $\%$ & $\mathrm{~N}$ & $\%$ \\
\hline $\begin{array}{l}\text { No Lab Available } \\
\text { Lab Available -No } \\
\text { participation }\end{array}$ & 23 & 100.0 & 0 & 0.0 \\
$\begin{array}{l}\text { Lab Available- } \\
\text { Participated }\end{array}$ & 0.0 & 0.0 & 8 & 33.3 \\
\hline
\end{tabular}


The ACT scores from the 2007 class with no laboratory had a mean of 23.96, a standard deviation of 3.77 , a minimum score of 18 , and a maximum score of 31 . Students in the 2009 class who chose not to participate in the laboratory had a mean ACT score of 24.75, a standard deviation of 3.92, a minimum score of 20, and a maximum score of 31 . The 2009 class who chose to participate in the optional laboratory had a mean ACT score of 24.75 , with a standard deviation of 4.42 , a minimum score of 18 , and a maximum score of 32 (see Table 2).

Table 2

Population Distribution by ACT Scores

\begin{tabular}{|c|c|c|c|c|c|c|c|c|}
\hline \multirow[b]{2}{*}{ ACT Scores } & \multicolumn{4}{|c|}{2007} & \multicolumn{4}{|c|}{2009} \\
\hline & Mean & $\mathrm{SD}$ & Min & Max & Mean & SD & Min & $\operatorname{Max}$ \\
\hline $\begin{array}{l}\text { No Lab } \\
\text { Available }\end{array}$ & 23.96 & 3.77 & 18 & 31 & 0.0 & 0.0 & 0.0 & 0.0 \\
\hline $\begin{array}{l}\text { Lab Available- } \\
\text { Did Not } \\
\text { Participate }\end{array}$ & 0.0 & 0.0 & 0.0 & 0.0 & 24.75 & 3.92 & 20 & 31 \\
\hline $\begin{array}{l}\text { Lab Available- } \\
\text { Participated }\end{array}$ & 0.0 & 0.0 & 0.0 & 0.0 & 24.75 & 4.42 & 18 & 32 \\
\hline
\end{tabular}

The final grades in the anatomy course in 2007 had a mean of $85.74 \%$, a standard deviation of 11.55 , a minimum grade of $62.13 \%$, and a maximum grade of $106.62 \%$. The student in 2009 who chose not to participate in the laboratory had a mean score of $84.36 \%$, a standard deviation of 11.08 , a minimum score of $66.33 \%$, and a maximum score of $100.53 \%$. The students in 2009 who chose to participate in the laboratory had a mean score of $85.31 \%$, a standard deviation of 15.13 , a minimum score of $49.13 \%$, and a maximum score of $101.60 \%$ (see Table 3 ). 
Table 3

Population by Final Grade

\begin{tabular}{lcccccccc}
\hline & \multicolumn{7}{c}{2007} & \multicolumn{5}{c}{2009} \\
\cline { 2 - 8 } Final Grade & Mean & SD & Min & Max & Mean & SD & Min & Max \\
\hline $\begin{array}{l}\text { No Lab } \\
\text { Available }\end{array}$ & 85.74 & 11.55 & 62.13 & 106.62 & 0.0 & 0.0 & 0.0 & 0.0 \\
$\begin{array}{l}\text { Lab Available- } \\
\text { No } \\
\text { participation }\end{array}$ & 0.0 & 0.0 & 0.0 & 0.0 & 84.36 & 11.08 & 66.33 & 100.53 \\
$\begin{array}{l}\text { Lab Available- } \\
\text { Participated }\end{array}$ & 0.0 & 0.0 & 0.0 & 0.0 & 85.31 & 15.13 & 49.13 & 101.60 \\
\hline
\end{tabular}

\section{Analysis of Covariance Comparing Final Grades}

The 2007 and 2009 semesters were offered as a lecture course in veterinary anatomy. The 2009 class had the option to have a laboratory in combination with the lecture, but the 2007 class was not offered a laboratory in conjunction with the lecture. Data was collected on the three groups which included their final grades in the lecture, final grade in the laboratory, and their SAT/ACT scores. The final grades and ACT scores where then analyzed to see if the laboratory had more of an effect on their final grade or if the standardized testing was a better estimate of their academic success in lecture.

An analysis of covariance was used to compare final grades between those who participated in the laboratory component and those who did not. ACT scores were used as a covariant as an equalizer on academic ability.

The hypothesis is that the lab had had an effect on the final grades in the anatomy lecture. The null hypothesis is that the lab had no effect on final grades in the anatomy 
lecture. The analysis was significant $(F=22.12, \alpha \leq 0.05)$. Due to the analysis I fail to reject the null. The model can explain $60.7 \%$ of the variance in the dependent variable. The $60.6 \%$ of variance is explained by the covariant ACT-SAT scores (see Table 4).

Table 4

Analysis of Covariance Comparing Final Grades in Veterinary Anatomy Course

\begin{tabular}{lcccccc}
\hline Source & $\begin{array}{c}\text { Type III } \\
\text { Sum of } \\
\text { Squares }\end{array}$ & DF & $\begin{array}{c}\text { Mean } \\
\text { Square }\end{array}$ & F & Sig. & $\begin{array}{c}\text { Partial Eta } \\
\text { Squared }\end{array}$ \\
\hline $\begin{array}{l}\text { Corrected } \\
\text { Model }\end{array}$ & $.441^{\mathrm{a}}$ & 3 & .147 & 22.120 & .000 & .607 \\
Intercept & $7.007 \mathrm{E}-02$ & 1 & $7.007 \mathrm{E}-02$ & 10.551 & .002 & .197 \\
ACT_SAT & .440 & 1 & .440 & 66.187 & .000 & .606 \\
Year & .000 & 0 & & & & .000 \\
Status & $4.856 \mathrm{E}-04$ & 1 & $4.856 \mathrm{E}-04$ & .073 & .788 & .002 \\
Year Status & .000 & 0 & & & & .000 \\
Error & .286 & 43 & $6.641-\mathrm{E}-03$ & & & \\
Total & 34.972 & 47 & & & & \\
Corrected & .726 & 46 & & & & \\
Total & & & & & & \\
\hline
\end{tabular}

a. $\quad$ R Squared $=.607$ (Adjusted R Squared $=.579$ )

\section{Students' Perceptions of the Value of the Laboratory Activities}

In the 2009 laboratory participants reported their levels of agreement on several statements related to the laboratory experiences. When asked if they thought the laboratory sessions were fun, three (20\%) reported being neutral, eight (53.3\%) agreed, and four (26.7\%) strongly agreed with the statement (see Table 5).

The participants were asked if they thought they gained any valuable information during the lab sessions. Five (33.3\%) individuals agreed, and 10 (66.7\%) strongly agreed with the statement (see Table 5). 
The students were asked if they thought the lab enhanced lecture material. Four respondents (26.7\%) agreed, and $11(73.3 \%)$ strongly agreed with the statement (see Table 5).

Participants were asked if the lab was essential part of their learning in anatomy. Six (40\%) individuals agreed, and nine (60\%) strongly agreed with the statement (see Table 5).

The participants were asked if they would struggle to learn anatomy without a laboratory. Two (13.3\%) respondents disagreed, four (26.7\%) students felt neutral, four (26.7\%) students agreed, and five (33.3\%) students strongly agreed with the statement (see Table 5).

The students were asked if they believed the laboratory was a waste of time. Nine $(60 \%)$ students strongly disagreed with the statement and six (40\%) disagreed (see Table $5)$.

The participants were asked if they would fail the course without the laboratory. Six $(40 \%)$ of the students strongly disagreed and six (40\%) students disagreed. One (6.7\%) student was neutral and one (6.7\%) student agreed with the statement. One (6.7\%) student strongly agreed with the statement (see Table 5).

Students were asked if they valued small group time in lab. Six (40\%) students strongly agreed, six (40\%) agreed, two (13.3\%) students felt neutral, and one $(6.7 \%)$ strongly disagreed. Participants were given the statement the laboratory was not offered with the lecture then they would not enroll in class. Two (13.3\%) students strongly disagreed, seven (46.7\%) disagreed, two (26.7\%) felt neutral, one (6.7\%) agreed, and one (6.7\%) strongly agreed with the statement (see Table 5). 
Table 5

Responses to Objective Sections of the Anatomy Survey

\begin{tabular}{|c|c|c|c|c|c|c|c|c|c|c|}
\hline & \multicolumn{2}{|c|}{$\begin{array}{l}\text { Strongly } \\
\text { disagree }\end{array}$} & \multicolumn{2}{|c|}{ Disagree } & \multicolumn{2}{|c|}{ Neutral } & \multicolumn{2}{|c|}{ Agree } & \multicolumn{2}{|c|}{ Strongly agree } \\
\hline & $\mathrm{N}$ & $\%$ & $\mathrm{~N}$ & $\%$ & $\mathrm{~N}$ & $\%$ & $\mathrm{~N}$ & $\%$ & $\mathrm{~N}$ & $\%$ \\
\hline The laboratory sessions are fun & 0 & 0.0 & 0 & 0.0 & 3 & 20.0 & 8 & 53.3 & 4 & 26.7 \\
\hline I gain valuable information from laboratory sessions & 0 & 0.0 & 0 & 0.0 & 0 & 0.0 & 5 & 33.3 & 10 & 66.7 \\
\hline The laboratory sessions enhance the lecture content & 0 & 0.0 & 0 & 0.0 & 0 & 0.0 & 4 & 26.7 & 11 & 73.3 \\
\hline $\begin{array}{l}\text { Laboratory sessions are an essential part of my } \\
\text { learning anatomy }\end{array}$ & 0 & 0.0 & 0 & 0.0 & 0 & 0.0 & 6 & 40.0 & 9 & 60.0 \\
\hline $\begin{array}{l}\text { I would struggle to learn anatomy if I did not have } \\
\text { the laboratory sessions }\end{array}$ & 0 & 0.0 & 2 & 13.3 & 4 & 26.7 & 4 & 26.7 & 5 & 33.3 \\
\hline The laboratory sessions are a waste of time & 9 & 60.0 & 6 & 40.0 & 0 & 0.0 & 0 & 0.0 & 0 & 0.0 \\
\hline I would fail anatomy without the laboratory sessions & 6 & 40.0 & 6 & 40. & 1 & 6.7 & 1 & 6.7 & 1 & 6.7 \\
\hline $\begin{array}{l}\text { I value the small group time I get in my laboratory } \\
\text { sessions }\end{array}$ & 1 & 6.7 & 0 & 0.0 & 2 & 13.3 & 6 & 40.0 & 6 & 40.0 \\
\hline $\begin{array}{l}\text { I would not enroll in the anatomy course if it had no } \\
\text { laboratory section }\end{array}$ & 2 & 13.3 & 7 & 46.7 & 4 & 26.7 & 1 & 6.7 & 1 & 6.7 \\
\hline
\end{tabular}


Table 5 (Continued)

Responses to Objective Sections of the Anatomy Survey

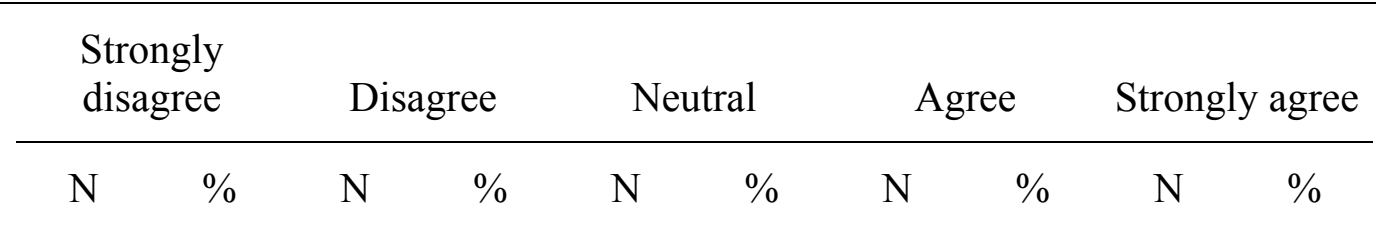

I can ask questions in laboratory sessions that I cannot ask in lectures

I can ask questions in laboratory session that I would not ask in lectures

\begin{tabular}{llllllllll}
0 & 0.0 & 2 & 13.3 & 6 & 40.0 & 5 & 33.3 & 2 & 13.3 \\
0 & 0.0 & 3 & 21.4 & 2 & 14.3 & 5 & 35.7 & 4 & 28.6 \\
0 & 0.0 & 0 & 0.0 & 7 & 46.7 & 4 & 26.7 & 4 & 26.7 \\
0 & 0.0 & 0 & 0.0 & 1 & 6.7 & 5 & 33.3 & 9 & 60.0 \\
0 & 0.0 & 1 & 6.7 & 2 & 13.3 & 5 & 33.3 & 7 & 46.7 \\
0 & 0.0 & 0 & 0.0 & 0 & 0.0 & 4 & 26.7 & 11 & 73.3 \\
\hline
\end{tabular}

Laboratory sessions should be required for the anatomy course

\begin{tabular}{llllllllll}
0 & 0.0 & 2 & 13.3 & 6 & 40.0 & 5 & 33.3 & 2 & 13.3 \\
0 & 0.0 & 3 & 21.4 & 2 & 14.3 & 5 & 35.7 & 4 & 28.6 \\
0 & 0.0 & 0 & 0.0 & 7 & 46.7 & 4 & 26.7 & 4 & 26.7 \\
0 & 0.0 & 0 & 0.0 & 1 & 6.7 & 5 & 33.3 & 9 & 60.0 \\
0 & 0.0 & 1 & 6.7 & 2 & 13.3 & 5 & 33.3 & 7 & 46.7 \\
0 & 0.0 & 0 & 0.0 & 0 & 0.0 & 4 & 26.7 & 11 & 73.3 \\
\hline
\end{tabular}

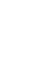

$13.3=6$

$\begin{array}{lll}40.0 & 5 & 33.3\end{array}$

Laboratory sessions help me better understand lecture material 
Table 5 (Continued)

Responses to Objective Sections of the Anatomy Survey

\begin{tabular}{|c|c|c|c|c|c|c|}
\hline $\begin{array}{l}\text { Strongly } \\
\text { disagree }\end{array}$ & Disagree & & & & & Strongly agree \\
\hline$\%$ & $\mathrm{~N}$ & $\mathrm{~N}$ & $\%$ & $\mathrm{~N}$ & $\%$ & $\%$ \\
\hline
\end{tabular}

I appreciate the hands-on time provided to me in laboratory sessions

0

$0.0 \quad 0$

0.0

The time to discuss anatomy with another member of staff (other than my primary lecturer) is valuable

\begin{tabular}{lllllllllll}
0 & 0.0 & 0 & 0.0 & 3 & 20.0 & 8 & 53.3 & 4 & 26.7 \\
0 & 0.0 & 1 & 6.7 & 0 & 0.0 & 4 & 26.7 & 10 & 66.7 \\
1 & 6.7 & 2 & 13.3 & 5 & 33.3 & 6 & 40.0 & 1 & 6.7 \\
0 & 0.0 & 1 & 7.1 & 2 & 14.3 & 7 & 50.0 & 4 & 28.6 \\
0 & 0.0 & 1 & 7.1 & 0 & 0.0 & 5 & 35.7 & 8 & 57.1 \\
7 & 46.7 & 7 & 46.7 & 1 & 6.7 & 0 & 0.0 & 0 & 0.0 \\
\hline
\end{tabular}

The time to discuss anatomy with a practicing veterinarian is valuable

\begin{tabular}{cccccccccc}
0 & 0.0 & 0 & 0.0 & 3 & 20.0 & 8 & 53.3 & 4 & 26.7 \\
0 & 0.0 & 1 & 6.7 & 0 & 0.0 & 4 & 26.7 & 10 & 66.7 \\
1 & 6.7 & 2 & 13.3 & 5 & 33.3 & 6 & 40.0 & 1 & 6.7 \\
0 & 0.0 & 1 & 7.1 & 2 & 14.3 & 7 & 50.0 & 4 & 28.6 \\
0 & 0.0 & 1 & 7.1 & 0 & 0.0 & 5 & 35.7 & 8 & 57.1 \\
7 & 46.7 & 7 & 46.7 & 1 & 6.7 & 0 & 0.0 & 0 & 0.0 \\
\hline
\end{tabular}

Laboratory session time should be used for my independent study of anatomy concepts

The time to discuss physiology with another member of staff (other than my primary lecturer) is valuable

The time to discuss physiology with a practicing veterinarian is valuable

The laboratory has had no effect on me understanding the lecture material 
Students were asked to the respond to the statement, "I could ask questions in lab that they cannot ask in class". Two (13.3\%) of the students disagreed, six (40\%) of the students felt neutral, five (35.7\%) of students agreed, and two (13.3\%) of the students strongly agreed (see Table 5).

Students were asked to the respond to the statement, "I would not ask questions in lab that they could ask in class". Two (21.4\%) of the students disagreed, six (14.3\%) of the students felt neutral, five (35.7\%) of students agreed, and four (28.6\%) of the students strongly agreed. The participants in laboratory were asked if they thought if the lab should be required for the course. Seven (46.7\%) were neutral, four (26.7\%) agreed, and four $(26.7 \%)$ strongly agreed with the statement (see Table 5).

The students were asked if the laboratory helped them in understanding lecture material. One (6.7\%) individual was neutral, five (33.3\%) agreed, and nine (60\%) strongly agreed with the statement. The participants were asked if the lab sessions allowed time to explore and look at anatomy posters and models. One (6.7\%) student disagreed with the statement. Two (13.3\%) students responded neutral, five (33.3\%) agreed, and seven (46.7\%) responded that they strongly agreed with the statement (see Table 5).

The students were asked if the specimen dissection was an important part of their laboratory sessions. Four (26.7\%) of the responses agreed with the statement, and eleven (73.3\%) students strongly agreed that specimens were important to the laboratory.

The survey asked if the students if they appreciated the hands on time during laboratory time. Two (13.3\%) of the students agreed with the statement and thirteen (86.7\%) students also agreed strongly (see Table 5). 
The participants were asked if they had time to have a valuable discussion about anatomy with another member of stuff and not just the lecturer. Three (20\%) were neutral on the question. Eight (53.3\%) students agreed with the statement and four $(26.7 \%)$ students strongly agreed.

Students were asked to the respond to the statement, "I had time have a valuable discussion about anatomy during laboratory time". One (6.7\%) student disagreed with that statement. Four (26.7\%) students agreed with the statement. Ten (66.7\%) responses strongly agreed with the statement (see Table 5).

The students were asked with the laboratory time should be used for independent study. One (6.7\%) student strongly disagreed with the statement, and two (13.3\%) responses disagreed. Five (33.3\%) students were neutral on their responses. Six (40\%) students agreed with the statement, and one (6.7\%) individual response was strongly agreed with the statement (see Table 5).

The participants were asked if they had time to discuss physiology with another member of the staff. One (7.1\%) students disagreed with the statement. Two $(14.3 \%)$ students felt neutral on the statement. Seven (50\%) agreed with the statement and four $(28.6 \%)$ responses strongly agreed (see Table 5$)$.

The participants were asked if they had time to discuss physiology with a practicing veterinarian. One $(7.1 \%)$ student disagreed with the statement. Five $(35.7 \%)$ agreed with the statement, and eight (57.1\%) responses strongly agreed with the statement (see Table 5).

The students were asked if they agreed with the statement, "The laboratory had no effect on their understanding of the course material”. Seven (46.7\%) students strongly 
disagreed with the statement and seven (46.7\%) responses disagreed. One (6.7\%) student reported neutral about the statement (see Table 5).

The 2009 laboratory class consisted of one sophomore $(\mathrm{N}=1,6.7 \%)$, three juniors $(\mathrm{N}=3,20 \%)$, and eleven seniors $(\mathrm{N}=11,73.3 \%)$. There were no freshmen enrolled during the 2009 animal anatomy with laboratory (see Table 6).

Table 6

Class Standing of Students Enrolled in 2009 Animal Anatomy Laboratory Class

\begin{tabular}{lcc}
\hline & $\mathrm{N}$ & $\%$ \\
\hline Sophomore & 1 & 6.7 \\
Junior & 3 & 20.0 \\
Senior & 11 & 73.3 \\
\hline
\end{tabular}

The past experience with animals varied among the 2009 students. Thirteen $(86.7 \%)$ students had been in laboratory classes with live animals. Twelve $(80 \%)$ of the students have had laboratory classes with animal cadavers. Fourteen $(93.3 \%)$ of the students had dissected an animal prior to participating in this class. Six (40\%) of the students had dissected an animal in a college laboratory other than in the animal anatomy laboratory. Four students $(26.7 \%)$ had dissected an animal on the University farm. Seven students (46.7\%) had dissected an animal with a veterinarian. Twelve students reported having dissected an animal by other means (see Table 7).

Eight $(53.3 \%)$ of the students had applied to veterinary school during the 2009 fall semester. Eleven (91.7\%) students planned on applying to veterinary school in the future (see Table 8). 


\section{Tables 7}

Past Experience with Animal Dissection of Students in 2009 Animal Anatomy Laboratory Class

\begin{tabular}{lcc}
\hline & $\mathrm{N}$ & $\%$ \\
\hline Lab Classes with Live Animals & 13 & 86.7 \\
Lab Classes with Animal Cadavers & 12 & 80.0 \\
Dissected an animal prior to this class & 14 & 93.3 \\
College lab & 6 & 40.0 \\
University farm & 4 & 26.7 \\
Veterinarian & 7 & 46.7 \\
Other & 12 & 80.0 \\
\hline
\end{tabular}

Table 8

Students Applications to Veterinary School

\begin{tabular}{lcc}
\hline & $\mathrm{N}$ & $\%$ \\
\hline Applied to veterinary school this year & 8 & 53.3 \\
Plan on applying to veterinary school & 11 & 91.7 \\
\hline
\end{tabular}

The students in the 2009 laboratory were asked to provide first, second, and third choices of what they wanted to do once they graduated. The students who preferred veterinary school included $75 \%(\mathrm{~N}=9)$ as first choice, $16.7 \%(\mathrm{~N}=2)$ as second choice, and $8.3 \%(\mathrm{~N}=1)$ reported vet school as a third choice (see Table 9).

The students were given graduate school as an option for a post- graduation. Three $(27.3 \%)$ respondents said that it was their first choice, four $(36.4 \%)$ listed it as their second choice, and four (36.4\%) had it as a third choice (see Table 9). 
The participants were asked if they would like to enter the work force. Three (33.3\%) students listed entering the workforce as second choice, and six (66.7\%) students listed it as their third choice (see Table 9).

The students were asked given, "other", as an option. Two (40\%) students listed it as their first choice and three (60\%) listed other as their second choice.

The participants were asked if they would like to apply to medical school. One $(100 \%)$ students placed it as a second choice (see Table 9).

Table 9

Plans Following Undergraduate in Order of Preference

\begin{tabular}{lcccccc}
\hline & \multicolumn{2}{c}{ First Choice } & \multicolumn{2}{c}{ Second Choice } & \multicolumn{2}{c}{ Third Choice } \\
\cline { 2 - 6 } & $\mathrm{N}$ & $\%$ & $\mathrm{~N}$ & $\%$ & $\mathrm{~N}$ & $\%$ \\
\hline Vet school & 9 & 75.0 & 2 & 16.7 & 1 & 8.3 \\
Graduate school & 3 & 27.3 & 4 & 36.4 & 4 & 36.4 \\
Enter work force & 0 & 0.0 & 3 & 33.3 & 6 & 66.7 \\
Other & 2 & 40.0 & 3 & 60.0 & 0 & 0.0 \\
Medical school & 0 & 0.0 & 1 & 100.0 & 0 & 0.0 \\
\hline
\end{tabular}

The first, second, and third place choices were recorded 3, 2, and 1 respectively. The responses were totaled across all respondents and used to rank the responses. Veterinary school placed first with a total of 32 points. Graduate school was placed second with 21 points. Workforce and other options were equivalent with 12 points each, and medical school was last with two points (see Table 10). 
Table 10

Total Points of Students Future Plans

\begin{tabular}{ll}
\hline & Sum \\
\hline Vet School & 32.00 \\
Graduate School & 21.00 \\
Work Force & 12.00 \\
Other & 12.00 \\
Medical School & 2.00 \\
\hline
\end{tabular}

Students were asked to indicate which veterinary school they had applied or planned to apply to this year or in the future. Twelve ( $80 \%)$ of students planned on applying to or had applied to Auburn University College of Veterinary Medicine. The applications to the University of Georgia College of Veterinary Medicine and Mississippi State University College of Veterinary included 11 (73.3\%) students each (see Table 11).

The Ohio State University College of Veterinary Medicine had a total of 5 (33.3\%) students who planned on applying or had already applied. Virginia Tech Virginia Maryland Regional College of Veterinary Medicine had a total of 5 (33.3\%) students who planned on applying or had already applied (see Table 11).

Tuskegee University School of Veterinary Medicine, University of Florida College of Veterinary Medicine, Purdue University School of Veterinary Medicine, The University of Minnesota College of Veterinary Medicine, Cornell University College of Veterinary Medicine, and North Carolina State University College of Veterinary Medicine had two students each (13.3\%) that had applied or planned on applying in the future (see Table 11). 
Table 11

Veterinary Schools Where Students Have Applied or Plan to Apply

\begin{tabular}{|c|c|c|}
\hline & $\mathrm{N}$ & $\%$ \\
\hline Auburn University College of Veterinary Medicine & 12 & 80.0 \\
\hline University of Georgia College of Veterinary Medicine & 11 & 73.3 \\
\hline Mississippi State University College of Veterinary Medicine & 11 & 73.3 \\
\hline The Ohio State University College of Veterinary Medicine & 5 & 33.3 \\
\hline $\begin{array}{l}\text { Virginia Tech Virginia Maryland Regional College of Veterinary } \\
\text { Medicine }\end{array}$ & 5 & 33.3 \\
\hline University of Pennsylvania School of Veterinary Medicine & 3 & 20.0 \\
\hline Tuskegee University School of Veterinary Medicine & 2 & 13.3 \\
\hline University of Florida College of Veterinary Medicine & 2 & 13.3 \\
\hline Purdue University School of Veterinary Medicine & 2 & 13.3 \\
\hline The University of Minnesota College of Veterinary Medicine & 2 & 13.3 \\
\hline Cornell University College of Veterinary Medicine & 2 & 13.3 \\
\hline North Carolina State University College of Veterinary Medicine & 2 & 13.3 \\
\hline University of California School of Veterinary Medicine & 1 & 6.7 \\
\hline $\begin{array}{l}\text { Western University of Health Sciences College of Veterinary } \\
\text { Medicine }\end{array}$ & 1 & 6.7 \\
\hline Colorado State University College of Veterinary Medicine & 1 & 6.7 \\
\hline University of Illinois College of Veterinary Medicine & 1 & 6.7 \\
\hline Michigan State University College of Veterinary Medicine & 1 & 6.7 \\
\hline Oklahoma State University College of Veterinary Medicine & 1 & 6.7 \\
\hline University of Tennessee College of Veterinary Medicine & 1 & 6.7 \\
\hline University of Wisconsin-Madison School of Veterinary Medicine & 1 & 6.7 \\
\hline Ross University School of Veterinary Medicine & 1 & 6.7 \\
\hline
\end{tabular}


University of California School of Veterinary Medicine, Western University of Health Sciences College of Veterinary Medicine, Colorado State University College of Veterinary Medicine, University of Illinois College of Veterinary Medicine, Michigan State University College of Veterinary Medicine, Oklahoma State University College of Veterinary Medicine, University of Tennessee College of Veterinary Medicine, University of Wisconsin-Madison School of Veterinary Medicine, and Ross University School of Veterinary Medicine all has one student (6.7\%) each interested in applying or had already applied for the 2009 academic year (see Table 11).

\section{Responses to Open Ended Questions about Laboratory Experience}

Students were asked in the survey what they enjoyed about the anatomy laboratory. A majority of the students responded that they enjoyed the hands on experience, having their own specimen, and reinforcing the lecture material. They also liked speaking with the instructor in a small group environment (see Appendix A).

The participants were asked what parts of the laboratory were most beneficial. They responded that the hands on time, reviewing material from lecture, and being able to interact with the instructor. A few of the participants also found exploring their cadavers to be beneficial (see Appendix B).

Students were asked to write down what they disliked about the laboratory. Most

of the students had issues with the grading system. Students recommended more than one exam. The participants also reported that they did not like one large time frame for lab, but would prefer multiple opportunities in smaller amounts of time in the lab (see Appendix C). 


\section{CHAPTER V}

\section{Conclusion, Summary, and Recommendations}

\section{Purpose of the Study}

The purpose of the study was to evaluate the effect on student comprehension of animal anatomy concepts with the addition of a hands-on laboratory experience. The study also sought to explore student's perceptions of the effectiveness of the laboratory. The results will provide insight to the instructors and administrators on how students learn the material best. The information may be used to improve existing laboratories or establish laboratories in other classes that are currently lecture only.

\section{Research Questions}

The objectives of the study are reflected in the following research questions:

1. What is the effect of the laboratory experience on grades for determining the learner's academic success in the animal anatomy course?

2. Do any significant differences exist between the grades of students who participated in the laboratory and those who did not take the optional laboratory?

3. What were the student's perceptions and feelings about the laboratory being offered in conjunction with the lecture?

4. Are the student's ACT/SAT scores a better predictor of their course grades regardless of the addition of the hands-on laboratory?

5. Should the laboratory be continued as an elective or required? 


\section{Population}

The population consisted of students enrolled in the animal anatomy course in the Department of Animal and Nutritional Sciences at West Virginia University during spring semesters of 2007 and $2009(n=47)$. The 2007 animal anatomy course was taught as lecture only with no laboratory offered (n=23). In 2009 an elective laboratory was offered to all students in addition to the lecture. Students self selected whether or not they took a laboratory in conjunction with lecture. Sixteen of the twenty-four $(66 \%)$ students enrolled in the animal anatomy course in 2009 elected to take the lecture laboratory combination, while 8 students (33\%) took only the lecture portion of the course.

Of the 23 students in the 2007 class, 100\% (N=23) did not have a laboratory available. In the 2009 class 24 students were enrolled in the lecture, of which the 24 students $(\mathrm{N}=8,33.3 \%)$ of the students chose not to participate in the laboratory. Sixteen of the students in 2009 chose to participate in the optional laboratory ( $N=16,66.7 \%$ ) (see Table 1).

\section{Summary}

The summary for this study is being presented using the study's research questions.

Research Question 1. The laboratory experience did not have a statically significant effect on the grades of the learner's academic success.

Research Question 2. While the laboratory did show a small effect (1\%) on the grades, it was not statistically significant (see Table 4). The students did 1\% better on their final grades than those who didn't participate in the laboratory with equivalent ACT scores (see Table 5). 
Research Question 3. The student's had overall positive feelings about participating in the laboratory in combination with the lecture. All of the students were in some level of agreement that they appreciated the hands-on time provided to them in the laboratory sessions. A majority of the participants thought the laboratory enhanced the lecture content and believed that the lab was an essential part of their learning anatomy. Overall the students enjoyed the general experience that the laboratory offered. While many of them did not necessarily do better in the course because of the laboratory the majority felt the lab was helpful.

Research Question 4. The student's ACT scores reflect on their course grades despite the addition of the laboratory. The ACT scores were found to be good indicators on how students would do in the course. The higher the ACT score, the higher the final grade was in the course.

Research Question 5. The laboratory could be continued as an elective for two reasons. Many of the students who enroll in the lecture are pre-veterinary undergraduates and as a result many of them are limited on the number of hours they can take. Leaving the class optional would free up more hours for required classes for veterinary school. Students would always have the option to take the laboratory later on in their academic career if they chose. The second reason is to let out side students whom may need some type of anatomy laboratory to meet requirements for another major. The laboratory could only help the students revisit lecture material a second time, and also would have an opportunity to see the animal's anatomy first hand. 


\section{Conclusions}

The study sought to determine whether or not addition of a hands on laboratory in combination with lecture would have an effect on the participants' final grades in the course. The students were found to have equivalent academic potential based on their ACT scores. The addition of the laboratory resulted in a minimal increase in grades among students with equal ACT scores. While their grades in the course were increased, the laboratory effect on the course grades was shown to have no statistical significance.

The study concluded that the students who scored higher on the standardized testing would have higher final grades in the anatomy course whether or not they participated in the laboratory. This would suggest that academic success rests more on ACT/SAT scores than what the laboratory provided. There was a small effect on the grades with the addition of the laboratory but ACT/SAT scores were a better predictor of final course grades

The students who chose to participate in the laboratory had more positive aspects than negative ones. The lab offered time to have one on one discussion with the instructor and the opportunity to converse with peers about anatomy. The hands on experience and exposure to real cadavers appeared to help the students with their associative learning. Students who participated in the lab in combination with the lecture expressed several positive outcomes of participation, including time to interact with the instructor, opportunity to have the hands on experience with specimens that reinforced lecture materials. Students recommended more than one exam in the lab settings and that they would prefer that the lab be broken into smaller time segments, instead of the large time block that was available. 


\section{Recommendations}

Based on the findings of this study the researchers offer the following recommendations would be suggested. The laboratory was found to be a great

opportunity for associative learning and it is recommended that the lab be continued as an elective. The recommendation to continue as an elective is to make the lab experience available to anatomy students to experience more hands on activity they may otherwise miss out on. Leaving the lab as optional for anatomy lecture students would provide them more flexibility in their schedules and would provide the opportunity for students to register of for the lab another semester. 


\section{REFERENCES}

Anatomy. (2009). In Merriam-Webster Online Dictionary. Retrieved September 23, 2009, from http://www.merriam-webster.com/dictionary/anatomy.

Ary, D., Jacobs, L.C., Razavieh, A., \& Sorenson, C. (2000). Introduction to research in education $\left(7^{\text {th }}\right.$ ed.). California: Thomson Wadsworth.

Beers, G. W., \& Bowden, S. (2005). The effect of teaching method on long-term knowledge retention. Nursing Education, 511-515.

Bolman, L. (1968). Laboratory education in a university executive program. Pittsburgh, PA.

Davis College of Agriculture, Natural Resources, and Design. (2009, January 2). Retrieved from West Virginia University: http://www.davis.wvu.edu/about_us

Johnston, A. N., \& McAllister, M. (2008). Back to the future with hands-on science: students' perceptions of learning anatomy and physiology. Nursing Education , 417-421.

Koenig, K., Frey, M., \& Detterman, D. (2008). ACT and general cognitive ability. Intelligence, $153-160$.

NCRR Strategic Plan 2009-2013: Translating research from basic discovery to improved patient care. (2007, December 3-4). Retrieved March 6, 2010, from National Center for Reseach Resource: http://www.ncrr.nih.gov/strategic_plan/online_version/initiative2.asp 
Odubunmi, O. (1991). The effect of laboratory and lecture teaching methods on cognitive achievement in integrated science. Journal of Research in Science Teaching , 213-224.

Piaget, J. (1954). Origins of intelligence in children. New York: International Universities Press.

Piaget, J. (1954). Retrieved from Webster's Dictionary Quotes.

SAT-ACT Concordance Tables. (2010). Retrieved January 14, 2010, from College Board: www.professionals.collegeboard.com 
APPENDICES 
APPENDIX A

Preferred activities from the Anatomy Laboratory 


\section{Question 31: What did you like best about the anatomy lab?}

-I liked being able to see in person what we saw on paper during the lecture. I also liked that we were

-Free to go at our own pace and dissect as much or as little as we wanted.

-The hands on experience. The cats.

-Hands on learning, laid back, group discussions, smaller group learning from professor, [Instructor]'s shared experiences, specimens from farm were great.

-Having our own animal and the instructions.

-The hands on experience.

•Hands on training/ learning.

-Hands on experience, being able to see and touch what we talked about in class. It was a relaxed and enjoyable learning atmosphere

-I liked it was a dissection lab which helped re-enforce what was learned in lecture. class size was small, [Instructor] was very helpful in explaining things. It helped me to understand material learned in class. I really liked the outside specimen brought in (kidneys, brains, eye balls)

-The smaller groups and the laid- back atmosphere during dissections

-Dissecting extra specimens, cecectomy surgery

•Hands on

-I liked applying the pictures seen in lecture to real life tangible animals

-Hands on experience with utensils, having our own cat, being able to dissect on our own and learn the techniques of dissection on our own, having other animals brought in other than the cat

-Necropsy and dissection 
APPENDIX B

Aspects that Students Found Most Beneficial from the Anatomy Laboratory 


\section{Question 32: What aspects of the lab were most beneficial?}

-Being able to see in $3 \mathrm{D}$ the structures that I has only seen on paper before

-The hands on experience.

-Being able to ask questions and discuss things in smaller group. Being hands on makes orientation of bones, muscles, nerves, vessels etc easier to understand and visual

-Having own cat and dissecting it, exploring on my own. Comparing to my neighbors cats.

the dissection and hands on with systems

-Being able to understand what you're looking at in 3D not just a word on paper.

-Having our own individual cats to work on

-Reviews

-Step-by-step dissection, but we could move at our own pace. We identified things ourselves and worked on our own.

-Seeing the internal variations between my cat and my neighbor's cat in lab, as well as being able to get input from a veterinarian while dissecting.

-Reviews with [Instructor]

-Actually seeing everything, extra time in the lab (other than lab days)

-It was most beneficial to keep reviewing the material in my head

- Being able to ask questions, having our own cat and own lab space

-Necropsy and dissection 
APPENDIX C

Dislikes From the Anatomy Laboratory 


\section{Question 33: What did you dislike about the anatomy lab?}

-I did not like the grading system. I think that there should be more considered in the grade then just the final.

-The amount of time we had (need more time) more one on one time is needed.

-Muscles were hard to remember

-Kind of going into it without covering it in class yet.

-The only grade being the final and how was it was disorganized sometimes

That it only has one grade for the class. I felt I knew the material but felt when the test came I was unsure of what part it was pointing at.

-It was a bit long sometimes, at least until we got stools to sit on

-I did not like that our only grade was the final. It was not structured, and we did not find out that the final was our only grade until the week before.

-I would like it if there was more than one grade for the whole semester.

The nauseating sheep tract..though it was beneficial for ruminant anatomy. But, wow, it was rank.

- No clear guidelines as to what to 'identify' and isolate while dissecting

-That the final was our only grade.

-The laboratory final was confusing. I felt like I knew most of the material but was confused about what the questions were indicating.

-Nothing, I loved anatomy lab

-Sometimes there could have been more discussion 
APPENDIX D

Recommendations to Improve the Anatomy Laboratory 


\section{Question 34: What recommendations would you like to make to improve the lab experience?}

- Possibly add quizzes or count attendance in the grade. Quizzes or add a midterm set up like the final would be better to prepare the students for final practical.

-Different species of animals to look at. Anatomy on a live animal have find certain organs etc.

more repro discussion, different species available, weekly or biweekly quizzes to help improve grade and help remember important info, more than just lab final for grade, i.e. participation and attendance, quizzes

-Going over "the book" bones/muscles before starting dissect them. Have more prep before dissect.

•Have more than just final. Get other cadavers than just cats (and "helpful" sheep)

-To have more than one grade for the class.

-The first few labs were frustrating because we were told to dissect an area without specific instructions; I think hand outs or guidelines would be very helpful, like step by step instructions

-Make lab structured, do not make the final the entire grade

- Count attendance toward the grade. Have copies of the lab book for everyone Seats for everyone! No real suggestions beyond that.

-Lab manual with pictures to look at while dissecting, more necropsies at the farm Have more grades throughout the lab.

- Only the lab final. The rest was enjoyable.

-Maybe make the lab a little shorter, from 2 hrs instead of 2 hrs and 50 mins.

-More necropsies on fresh specimen 
APPENDIX E

Anatomy Laboratory Satisfaction Survey 


\section{Veterinary Anatomy}

Laboratory

Impact Study

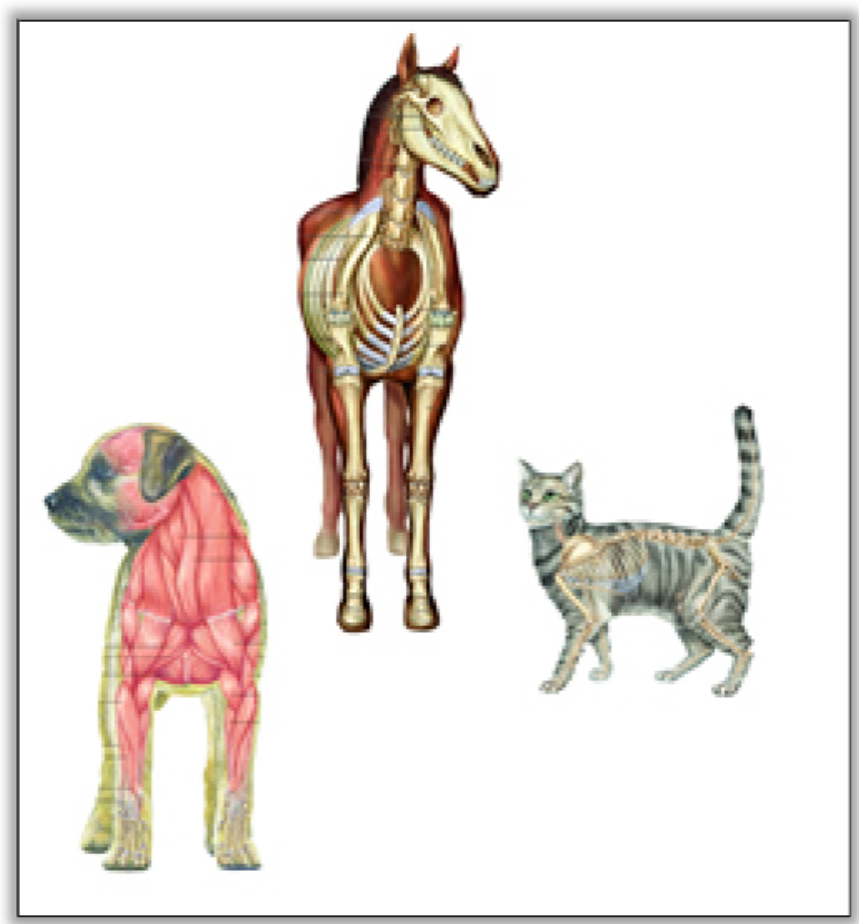

Bess Hammill

Graduate Student

Agricultural and Extension Education

Davis College of Agriculture, Forestry, and Consumer Sciences

West Virginia University

Morgantown, WV 26506 


\section{Veterinary Anatomy Laboratory Impact Study}

Instructions: Using the Likert scale, rate your opinion on each of the following anatomy class- related statements. Indicate your opinion by circling the letters that best correspond to your response: SA- Strongly Agree, A- Agree, N- Neutral, D- Disagree, SD- Strongly Disagree.

Example:

\begin{tabular}{|c|c|c|c|c|c|}
\hline Statement & 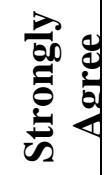 & 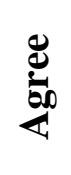 & 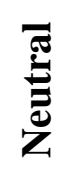 & 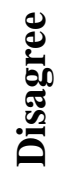 & 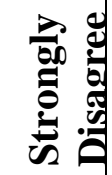 \\
\hline $\begin{array}{l}\text { The Mountaineers are the best football team in } \\
\text { the NCAA. }\end{array}$ & & A & $\mathrm{N}$ & $\mathrm{D}$ & $\mathrm{SD}$ \\
\hline
\end{tabular}

\begin{tabular}{|c|c|c|c|c|c|}
\hline Statement & 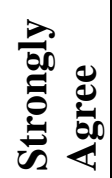 & & ل & 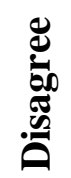 & 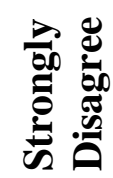 \\
\hline 1. The laboratory sessions are fun. & SA & $\mathrm{A}$ & $\mathrm{N}$ & $\mathrm{D}$ & SD \\
\hline $\begin{array}{l}\text { 2. I gain valuable information from } \\
\text { laboratory sessions. }\end{array}$ & SA & $\mathrm{A}$ & $\mathrm{N}$ & $\mathrm{D}$ & SD \\
\hline
\end{tabular}




\begin{tabular}{|c|c|c|c|c|c|}
\hline Statement & 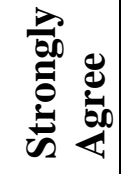 & مِّ & $\begin{array}{l}\bar{\pi} \\
\bar{z} \\
\bar{z}\end{array}$ & 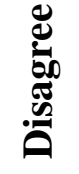 & 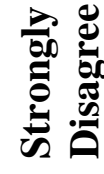 \\
\hline $\begin{array}{l}\text { 3. The laboratory sessions enhance the } \\
\text { lecture content. }\end{array}$ & SA & A & $\mathrm{N}$ & $\mathrm{D}$ & SD \\
\hline $\begin{array}{l}\text { 4. Laboratory sessions are an essential part of } \\
\text { my learning anatomy. }\end{array}$ & SA & A & $\mathrm{N}$ & D & SD \\
\hline $\begin{array}{l}\text { 5. I would struggle to learn anatomy if I did } \\
\text { not have the laboratory sessions. }\end{array}$ & SA & $\mathrm{A}$ & $\mathrm{N}$ & $\mathrm{D}$ & SD \\
\hline $\begin{array}{l}\text { 6. The laboratory sessions are a waste of } \\
\text { time. }\end{array}$ & SA & A & $\mathrm{N}$ & $\mathrm{D}$ & SD \\
\hline $\begin{array}{l}\text { 7. I would fail anatomy without the } \\
\text { laboratory sessions. }\end{array}$ & SA & $\mathrm{A}$ & $\mathrm{N}$ & $\mathrm{D}$ & SD \\
\hline $\begin{array}{l}\text { 8. I value the small group time I get in my } \\
\text { laboratory sessions. }\end{array}$ & SA & A & $\mathrm{N}$ & $\mathrm{D}$ & SD \\
\hline $\begin{array}{l}\text { 9. I would not enroll in the anatomy course } \\
\text { if it had no laboratory section. }\end{array}$ & SA & $\mathrm{A}$ & $\mathrm{N}$ & $\mathrm{D}$ & SD \\
\hline $\begin{array}{l}\text { 10. I can ask questions in laboratory sessions } \\
\text { that I cannot ask in lectures. }\end{array}$ & SA & A & $\mathrm{N}$ & $\mathrm{D}$ & SD \\
\hline $\begin{array}{l}\text { 11. I can ask questions in laboratory session } \\
\text { that I would not ask in lectures. }\end{array}$ & SA & $\mathrm{A}$ & $\mathrm{N}$ & $\mathrm{D}$ & SD \\
\hline $\begin{array}{l}\text { 12. Laboratory sessions should be required for } \\
\text { the anatomy course. }\end{array}$ & SA & A & $\mathrm{N}$ & $\mathrm{D}$ & SD \\
\hline $\begin{array}{l}\text { 13. Laboratory sessions help me better } \\
\text { understand lecture material. }\end{array}$ & SA & $\mathrm{A}$ & $\mathrm{N}$ & $\mathrm{D}$ & SD \\
\hline
\end{tabular}




\begin{tabular}{|c|c|c|c|c|c|}
\hline Statement & 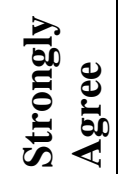 & 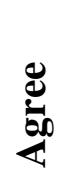 & 氖 & 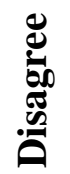 & 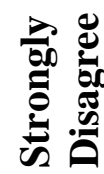 \\
\hline $\begin{array}{l}\text { 14. The laboratory sessions allow for time to } \\
\text { explore the animal anatomy posters and } \\
\text { models are important part of my laboratory } \\
\text { time. }\end{array}$ & SA & $\mathrm{A}$ & $\mathrm{N}$ & $\mathrm{D}$ & SD \\
\hline $\begin{array}{l}\text { 15. I find the specimen dissections an } \\
\text { important part of my laboratory time. }\end{array}$ & SA & A & $\mathrm{N}$ & $\mathrm{D}$ & SD \\
\hline $\begin{array}{l}\text { 16. I appreciate the hands-on time provided to } \\
\text { me in laboratory sessions. }\end{array}$ & SA & $\mathrm{A}$ & $\mathrm{N}$ & $\mathrm{D}$ & SD \\
\hline $\begin{array}{l}\text { 17. The time to discuss anatomy with another } \\
\text { member of staff (other than my primary } \\
\text { lecturer) is valuable. }\end{array}$ & SA & A & $\mathrm{N}$ & $\mathrm{D}$ & SD \\
\hline $\begin{array}{l}\text { 18. The time to discuss anatomy with a } \\
\text { practicing veterinarian is valuable. }\end{array}$ & SA & $\mathrm{A}$ & $\mathrm{N}$ & $\mathrm{D}$ & SD \\
\hline $\begin{array}{l}\text { 19. Laboratory session time should be used } \\
\text { for my independent study of anatomy } \\
\text { concepts. }\end{array}$ & SA & $\mathrm{A}$ & $\mathrm{N}$ & $\mathrm{D}$ & SD \\
\hline $\begin{array}{l}\text { 20. The time to discuss physiology with } \\
\text { another member of staff (other than my } \\
\text { primary lecturer) is valuable. }\end{array}$ & SA & $\mathrm{A}$ & $\mathrm{N}$ & $\mathrm{D}$ & SD \\
\hline $\begin{array}{l}\text { 21. The time to discuss physiology with a } \\
\text { practicing veterinarian is valuable. }\end{array}$ & SA & $\mathrm{A}$ & $\mathrm{N}$ & $\mathrm{D}$ & SD \\
\hline $\begin{array}{l}\text { 22. The laboratory has had no effect on me } \\
\text { understanding the lecture material. }\end{array}$ & SA & A & $\mathrm{N}$ & $\mathrm{D}$ & SD \\
\hline
\end{tabular}


23. What year in school are you currently:

Freshmen

Sophomore

Junior

Senior

_ Graduate Student

24. Have you ever had lab classes involving live animals?

Yes__ No

25. Have you ever had lab classes involving animal cadavers?

Yes _ No

26. Have you ever dissected an animal prior to this class?

No

Yes (If yes, please indicate where, check all that apply)

a. In a college lab

b. On the University farm

c. With a veterinarian

d. Other (Please specify)

27. Have you applied to veterinary school this year?

Y Yes _ N No

28. Do you plan on applying to veterinary school?

Yes (If yes go to \#27)

No (If no then skip \#27 and go to \#28)

29. What are your plans if you not accepted ("Plan B") or an alternative to veterinary school? (Please specify your top 3 chooses)

a. Vet school

b. Graduate School

c. Enter work force

d. Other

e. Medical school 
30. What school do you plan on applying or have already applied to (check all that apply):

\section{College of Veterinary Medicine}

Tuskegee University School of Veterinary Medicine

University of California School of Veterinary Medicine

Western University of Health Sciences College of Veterinary

Medicine

Colorado State University College of Veterinary Medicine

University of Florida College of Veterinary Medicine

University of Georgia College of Veterinary Medicine

University of Illinois College of Veterinary Medicine

Purdue University School of Veterinary Medicine

Iowa State University College of Veterinary Medicine

Kansas State University College of Veterinary Medicine

Louisiana State University School of Veterinary Medicine

Tufts University School of Veterinary Medicine

Michigan State University College of Veterinary Medicine

The University of Minnesota College of Veterinary Medicine

Mississippi State University College of Veterinary Medicine University of Missouri-Columbia College of Veterinary Medicine Cornell University College of Veterinary Medicine North Carolina State University College of Veterinary Medicine The Ohio State University College of Veterinary Medicine Oklahoma State University College of Veterinary Medicine Oregon State University College of Veterinary Medicine University of Pennsylvania School of Veterinary Medicine University of Tennessee College of Veterinary Medicine Texas A\&M University College of Veterinary Medicine \& Biomedical Sciences Virginia Tech Virginia-Maryland Regional College of Veterinary Medicine Washington State University College of Veterinary Medicine University of Wisconsin-Madison School of Veterinary Medicine Ross University School of Veterinary Medicine Other (Out of country or vet school not listed, please specify)

31. What did you like best about the anatomy lab? 
32. What aspects of the lab were most beneficial?

33. What did you dislike about the anatomy lab?

34. What recommendations would you like to make to improve the lab experience?

(-) Thank you for completing this survey. 
APPENDIX F

\section{Cover Letter to Students}


April 27, 2009

Dear Anatomy Laboratory Student:

Today you are receiving a survey regarding your views on the impact of combining the hands on laboratory with the veterinary anatomy lecture. All of you are enrolled in the laboratory to further your veterinary anatomy understanding and you are the future of the agriculture and animal science industries. The survey is the instrument that will be used to gather your views on the impact of combining the hands on laboratory with the veterinary anatomy lecture.

I am Bess Hammill, a graduate student in Agricultural and Extension Education at West Virginia University and a recent graduate of the Animal Science department. Under the direction of my advisor, Dr. Deborah A. Boone, I am conducting a research study to determine the impact of an interactive laboratory paired with the traditional anatomy lecture. The results of this study will be used to prepare a thesis to partially fulfill the requirements for a Master's of Science degree in Agricultural and Extension Education. West Virginia University's IRB acknowledgement of this study is on file. By finding out your position towards the anatomy laboratory and lecture the results will impact how the course will be taught, whether or not the laboratory is offered and how lecture material is distributed.

You must be 18 years of age or older to participate in this survey. Your participation in this research study is solely voluntary and will have no impact on your veterinary anatomy course grade or class standing. You may stop filling out this survey at any time or skip any question you do not wish to answer. However, your completion of the survey is crucial to the success of this study. The survey should only take about 10 minutes and your results will be held as confidential as possible.

Please complete the survey and return it to the person administering the survey. If you have questions, you may contact Dr. Boone at Debby.Boone@mail.wvu.edu or by phone at 304-293-4832 x4482. Bess can be reached at bhammill@mix.wvu.edu. Thank you and we sincerely appreciate you taking the time and effort to complete this survey.

Sincerely,

Bess Hammill

Graduate Student
Deborah A. Boone, Ph.D.

Assistant Professor 


\section{VITA}

Bess Hammill

Education:

May 2004

May 2008

May 2010

Professional Experiences:
Shaler Area High School

Graduated with Honors

Pittsburgh, Pennsylvania

Bachelor's of Science

Animal and Nutritional Sciences

West Virginia University

Morgantown, West Virginia

Master's of Science

Agricultural and Extension Education

West Virginia University

Morgantown, West Virginia

May 2004- 2006 NCAA Athlete, Rowing

Captain: 2004-2005

West Virginia University

Morgantown, West Virginia

May 2006- 2008 Farm Worker, Dairy

West Virginia University

Morgantown, West Virginia

Hillcrest Veterinary Clinic

Clinical Assistant

Morgantown, West Virginia 